\title{
Studies on the $\beta$-lactamase production of bacterial isolates from smoked bush meats correlated with bacterial resistance to three $\beta$-lactam antibiotics
}

\author{
*KAYODE, R.M.O' ${ }^{\text {.; KOLAWOLE, O. M. }}{ }^{2}$ \\ ${ }^{1}$. Division of Biotechnology, Department of Animal Production, P.M.B 1515, University of Ilorin, Ilorin, Nigeria. E-mail; \\ kayodermosnr@yahoo.com. Phone No: 08035850545. Department of Microbiology, University of Ilorin, P.M.B 1515 Ilorin. E-mail; \\ tomak74@yahoo.com,omk@unilorin.edu.ng.Phoneno; 08060088495
}

\begin{abstract}
Eight bacterial species were isolated from smoked meats and screened for the production of $\beta$-lactamase; which was detected by penicillin impregnated starch paper strips. $\beta$-lactamase was detected in the following bacterial isolates: Klebsiella pneumoniae (75.0\%), Escherichia coli (69.7\%), Proteus sp. (33.3\%), Pseudomonas aureginosa (25.9\%), Staphylococcus aureus (80.0\%) and Streptococcus feacalis (12.5\%). There was no $\beta$-lactamase detected in Lactobacillus casei and Salmonella sp. isolated from the meats. The prevalence of $\beta$-lactamase detected in the samples shows that the bacteria posses the potential to produce $\beta$-lactamase irrespective of the source of isolation. The sensitivity of the $\beta$-lactam antibiotics (penicillin G, ampicillin and cloxacillin) used range from $8.3-100.0 \%$. Although, penicillin $\mathrm{G}$ has the lowest sensitivity of $8.3 \%$ to Klebsiella pneumoniae while, ampicillin and cloxacillin were $25.0 \%$ and $16.7 \%$ sensitive to the same bacteria respectively. Salmonella species is the most susceptible (range from $70.0-100.0 \%$ ) to the tested antibiotics among the $\beta$-lactamase positive bacteria screened. The frequency of occurrence of the pathogenic bacteria and the feacal indicator organism (E.coli) indicated gross contamination of some of the meat samples analyzed; this indicates that the meats may have been contaminated either during processing with faecal contaminated water or handling by the sellers. In conclusion, the habit of eating uncooked smoked meat should be discouraged and emphasis should be laid on properly cooked meat before consumption. @ JASEM
\end{abstract}

Smoking of meat samples dates back to prehistoric times in Nigeria. The procedures were originally developed to yield products with characteristic texture, colour, odour and flavour of a particular region in Nigeria. These characteristics were largely determined by available and types of meat, spices and other raw materials, methods of smoke production, the duration of processing, humidity and temperature used. High quality in terms of texture, flavour, colour and odour can only be assessed organoleptically; this is why some people consume smoked meat and fish without washing with water before consumption. Bacterial infections remain a significant cause of morbidity in tropical countries. The introduction of penicillin in the 1940s heralded a major life saving breakthrough in the fight against infections caused by many gram-positive and some gram-negative microorganisms including Klebsiella, Escherichia coli, Neisseria meningitidis and many others (Lynne and Bernard, 1991). Among gram-positive anaerobic bacteria, $\beta$-lactamases have been found in Clostridium (Appelbaum et al; 1994) Rotimi (1989) reported that the production of $\beta$-lactamase enzyme is the most common antibacterial resistance to $\beta$-lactam antibiotics in gram-negative and gram-positive bacteria. This study aims at investigating the prevalence of $\beta$-lactamase production by bacteria isolated from different smoked meat samples and the susceptibility pattern of the isolates to some $\beta$-lactam antibiotics in Ilorin metropolis.

\section{MATERIALS AND METHODS}

Forty eight smoked bush meat samples (12 samples each) from Grass-cutter, wild rabbit, Monitor lizard and Antelope were purchased from four (4) major markets in Ilorin metropolis into sterile specimen bottles; the samples were taken to the laboratory for analysis immediately after collection.

\section{ISOLATION AND IDENTIFICATION OF BACTERIAL ISOLATES}

Nutrient and Mac-Conkey agar were sterilized at $121^{\circ} \mathrm{C}$ for $15 \mathrm{~min}$. and used for the cultivation and enumeration of the isolated bacteria from the smoked bush meat samples.

The colonial morphology and biochemical tests were carried out according to Barrow and Feltham (1995) to confirm the identify of each of the isolates. While pure culture of the bacteria was inoculated on slants of blood agar base in bijou bottles, incubated at $37^{\circ} \mathrm{C}$ and stored in the refrigerator until needed for $\beta$-lactamase screening.

\section{POSITIVE AND NEGATIVE CONTROL BACTERIA}

Staphylococcus aureus strain was used as a positive control, while a confirmed $\beta$-lactamase negative strain of Streptococcus faecalis obtained from the University of Ilorin Teaching Hospital were used.

\section{SCREENING OF BACTERIAL ISOLATES FOR $\beta$-LACTAMASE PRODUCTION}

One hundred and seventy-seven (177) bacterial strains consisting of the identified eight bacteria species isolated from the various bush meat samples were tested for the production of $\beta$ lactamase. 


\section{PENICILLIN STARCH PAPER STRIPS PREPARATION}

Penicillin starch paper strip was prepared according to the method used in a study on paediatric gonorrhoea (Odugbemi and Onile, 1988). An ample of benzyl penicillin containing 1,000,000 iu of antibiotic was dissolved in $10 \mathrm{ml}$ of phosphate buffered saline (PBS) at $\mathrm{pH} 7.3$ such that each $\mathrm{ml}$ of the solution contain 100,000 iu of benzyl penicillin.

Two percent $(2 \%)$ starch solution was prepared by the addition of $2 \mathrm{~g}$ of starch powder to $98 \mathrm{ml}$ of phosphate buffered saline; the starch was warmed until dissolved completely. A whatman no 3 filter paper was cut into strips of size $7 \mathrm{~cm}$ by $4 \mathrm{~cm}$ to fit the bottom of the petri-dish. $10 \mathrm{ml}$ of the benzyl penicillin solution was added to $90 \mathrm{ml}$ of the $2 \%$ starch solution and mixed properly. The paper strips are then soaked in the mixture for $5 \mathrm{~min}$, removed and spread in a hood to dry and stored in the refrigerator at $4^{\circ} \mathrm{C}$ before use.

\section{DETECTION OF $\boldsymbol{\beta}$-LACTAMASE}

A strip of the starch paper was soaked in benzyl penicillin for $10 \mathrm{~min}$ and spread smoothly in a neat petri-dish. Two millimeter sterile bacteriological loop was used to collect bacterial culture from the surface of the blood agar slants and transferred to the test paper in a petri-dish; this was spread smoothly over an area of $2-3 \mathrm{~mm}$, inocula were placed at least $1.5 \mathrm{~cm}$ apart. These were incubated at $37^{\circ} \mathrm{C}$ for $30 \mathrm{~min}$ after which the paper was flooded with iodine solution (which was drained immediately). This causes the starch to turn uniformly blue black; a negative region also turn blue black, white positive result in a region where the bacteria produces $\beta$-lactamase becomes decolourized immediately.

\section{SENSITIVITY TEST}

Antibiotic sensitivity multi-discs containing ampicillin, penicillin and cloxacillin were used for this work.

\section{STATISTICAL ANALYSIS}

Data collected on the $\beta$-lactamase production by the bacterial isolates and the susceptibility of the bacteria to $\beta$-lactam antibiotics were analyzed by simple descriptive statistics while, that on the bacterial counts of the of bush meats were analyzed using 4 x 4 factorial design (Steel and Torie, 1980). Where significant different were obtained between treatment means, the means were further subjected to Duncan's New multiple range test as outlined by Obi (2003).

\section{RESULTS AND DISCUSSIONS}

Eight bacterial isolates were obtained from the bush meat samples used for this experiment. The isolates were identified as Klebsiella pneumoniae, Staphylococcus aureus, Escherichia coli, Streptococcus faecalis, Lactobacillus casei, Proteus sp., Salmonella sp. and Pseudomonas aureginosa (Table 1).

TABLE 1: Occurrence of Bacterial Isolates from Smoked Bush Meats tested in Ilorin Metropolis

\begin{tabular}{|c|c|c|c|c|c|c|c|c|c|c|c|c|c|c|c|c|}
\hline \multirow{2}{*}{$\begin{array}{l}\text { Bacterial } \\
\text { isolates }\end{array}$} & \multicolumn{4}{|c|}{ Grass cutter } & \multicolumn{4}{|c|}{ Monitor lizard } & \multicolumn{4}{|c|}{ Wild rabbit } & \multicolumn{4}{|c|}{ Antelope } \\
\hline & IP & EM & BA & GA & IP & EM & BA & GA & IP & EM & $\mathbf{B A}$ & GA & IP & EM & BA & GA \\
\hline $\begin{array}{l}\text { Escherichia } \\
\text { coli }\end{array}$ & 3 & 3 & 3 & 3 & 2 & - & 2 & 1 & 3 & - & 3 & 3 & 3 & 1 & 2 & 1 \\
\hline $\begin{array}{l}\text { Klebsiella } \\
\text { pneumoniae }\end{array}$ & - & - & - & 3 & 1 & - & 2 & 2 & - & - & 3 & - & - & - & 1 & - \\
\hline $\begin{array}{l}\text { Proteus } \\
\text { species }\end{array}$ & 1 & 1 & 3 & - & 2 & - & - & - & 2 & - & 3 & - & - & 2 & 1 & - \\
\hline $\begin{array}{l}\text { Psuedomonas } \\
\text { aeruginosa }\end{array}$ & 2 & - & 1 & 3 & - & 3 & 2 & 1 & - & 3 & 3 & - & 3 & 3 & 3 & - \\
\hline $\begin{array}{l}\text { Salmonella } \\
\text { species }\end{array}$ & 2 & - & - & 1 & 2 & - & - & - & 2 & 1 & - & 1 & 1 & - & - & - \\
\hline $\begin{array}{l}\text { Staphylo coccus } \\
\text { aureus }\end{array}$ & 3 & 3 & 3 & - & 3 & 2 & 3 & 1 & 1 & 3 & 3 & 3 & 3 & 3 & 3 & 3 \\
\hline $\begin{array}{l}\beta \text {-heamolytic } \\
\text { Strepto } \\
\text { coccus }\end{array}$ & 3 & 3 & 2 & 2 & - & 2 & 2 & 3 & - & - & - & 2 & 2 & 3 & - & - \\
\hline $\begin{array}{l}\text { Lactobacillus } \\
\text { casei }\end{array}$ & 3 & - & 2 & 3 & - & 2 & - & - & 2 & - & 1 & - & 2 & 1 & - & - \\
\hline
\end{tabular}

\footnotetext{
1 = isolated from one replicate sample only

2 = isolated from two replicate samples only

3 = isolated from three replicate samples only

$=$ not present in the three replicate samples use

$\mathrm{Ip}=$ Ipata; $\mathrm{EM}=$ Emir; $\mathrm{BA}=$ Baboko; $\mathrm{GA}=$ Ganmo
}

Generally, the bacterial counts obtained in the bush meats bought at Ipata market had the highest values $(p>0.05)$ when compared with those from other markets within the same region in Ilorin metropolis (Table 2) 
TABLE 2: Bacterial Counts of smoked bush meat from four (4) markets in ilorin metropolis

\begin{tabular}{|c|c|c|c|c|}
\hline \multirow[t]{2}{*}{ Meat type/market } & \multicolumn{3}{|c|}{ Bacterial counts $\left(\mathrm{x} 10^{3} \mathrm{cfu} / \mathrm{g}\right)$} & \multirow[b]{2}{*}{ Ganmo } \\
\hline & Ipata & Emir & Baboko & \\
\hline Grass cutter & $20.0^{\mathrm{a}}$ & $10.7^{\mathrm{ab}}$ & $10.4^{\mathrm{a}}$ & $16.0^{\mathrm{a}}$ \\
\hline Monitor lizard & $4.9^{\mathrm{b}}$ & $1.0^{\mathrm{c}}$ & $2.1^{\mathrm{b}}$ & $2.4^{\mathrm{c}}$ \\
\hline Wild rabbit & $18.7^{\mathrm{a}}$ & $7.5^{\mathrm{b}}$ & $11.7^{\mathrm{a}}$ & $8.6^{\mathrm{b}}$ \\
\hline Antelope & $16.6^{\mathrm{a}}$ & $13.1^{\mathrm{a}}$ & $10.9^{\mathrm{a}}$ & $9.7^{\mathrm{b}}$ \\
\hline
\end{tabular}

Means within the same column followed by the same letter(s) are not significantly different $(\mathrm{p} \leq 0.05)$ according to Duncan's new Multiple Range Test.

While the bacterial counts of smoked monitor lizard bought from the four (4) markets are significantly lower $(\mathrm{p}<0.05)$ when compared with count obtained for other meat samples used for this work. The higher values obtained in meats bought from Ipata market; apart from poor meat processing methods, may be the result of poor sanitary practices and the population congestion, experience in the market.

Most of the isolated bacteria are pathogenic and associated with the production of $\beta$-lactamase (Table 3)

TABLE 3: Incidence of $\beta$-lactamase production in the bacterial isolates from smoked bush meats

\begin{tabular}{|c|c|c|c|c|}
\hline $\begin{array}{l}\text { Bacterial } \\
\text { Isolates }\end{array}$ & $\begin{array}{l}\text { No. of isolates } \\
\text { screened }\end{array}$ & $\begin{array}{l}\text { Percentage of } \\
\text { total isolates } \\
\text { screened }\end{array}$ & $\begin{array}{l}\beta \text {-lactamase } \\
\text { positive isolates }\end{array}$ & $\begin{array}{l}\text { Percentage of } \beta \text { - } \\
\text { lactamase } \\
\text { positive of each } \\
\text { bacterial isolates }\end{array}$ \\
\hline $\begin{array}{l}\text { Escherichia } \\
\text { Coli }\end{array}$ & 33 & 18.6 & 23 & 69.7 \\
\hline $\begin{array}{l}\text { Klebsiella } \\
\text { Pneumoniae }\end{array}$ & 12 & 6.8 & 9 & 75.0 \\
\hline $\begin{array}{l}\text { Proteus } \\
\text { Species }\end{array}$ & 15 & 8.5 & 5 & 33.3 \\
\hline $\begin{array}{l}\text { Pseudomonas } \\
\text { aeruginosa }\end{array}$ & 27 & 15.3 & 7 & 25.9 \\
\hline $\begin{array}{l}\text { Salmonella } \\
\text { Species }\end{array}$ & 10 & 5.7 & 0 & 0.0 \\
\hline $\begin{array}{l}\text { Staphylococcus } \\
\text { Aureus }\end{array}$ & 40 & 22.6 & 32 & 80.0 \\
\hline $\begin{array}{l}\beta \text {--Heamolytic } \\
\text { Streptococcus }\end{array}$ & 24 & 13.5 & 3 & 12.5 \\
\hline $\begin{array}{l}\text { Lactobacillus } \\
\text { Casei }\end{array}$ & 16 & 9.0 & 0 & 0.0 \\
\hline Total & 177 & 100.0 & 79 & \\
\hline
\end{tabular}

This enzyme inactivates the $\beta$-lactam antibiotics and prevents it from reaching its target sites. This resistance may however not be solely dependent of $\beta$-lactamase production as factors such as changes in the permeability of bacterium's outer membrane and alternation in bacterium penicillin binding protein (Rotimi, 1989). The tested bacteria consist of both gram positive and gram negative rods as shown in table1. Of the eight (8) bacteria isolates tested; twenty five percent $(25.0 \%)$ were grampositive pathogens, the incidence of the bacterial isolates screened for $\beta$-lactamases is shown in table 3; Staphylococcus aureus predominate with 40 isolates $(22.6 \%)$ followed by Escherichia coli 33 isolates (18.6\%) Salmonella $s p$. is the least tested with only 10 isolates $(5.7 \%)$ of the total bacterial isolates from the meat samples used; $44.63 \%$ of the total bacterial isolates tested were $\beta$-lactamase positive including $24.9 \%$ gram negative and $19.87 \%$ gram positive bacteria. At least three quarters of Streptomyces strains from the soil were reported to have produced $\beta$-lactamase constitutively and extracellularly in a studies carried out by Ogarawa et al., (1978) on the comparison of the production and property for $\beta$ lactamase in Streptomyces, isolated newly and thirty years ago. Ogarawa et al., (1999) reported only $5.51 \% \quad \beta$-lactamase production in actinomycete strains; which is a low frequency in contrast to the case reported by Ogarawa et al., (1978) with Streptomyces species: The $\beta$ lactamase positive actinomycete strains were reported not related phylogenically and the MICs of benzyl penicillin was reported not correlated with $\beta$-lactamase production. The incidence of $\beta$ lactamase production in the bacteria tested is as shown in table 3.

In this study $91.67 \%$ of Klebsiella pneumoniae isolates were resistant to penicillin; this value is higher than $88.0 \%$ in a study carried out by Lynee and Bernard (1991). This report shows Staphylococcus aureus resistance to be $65.0 \%$ for ampicillin and $85.0 \%$ for penicillin G (Table 4 ). 
TABLE 4: $\beta$-lactam antibiotics susceptibility pattern to the bacterial isolates from smoked bush meats.

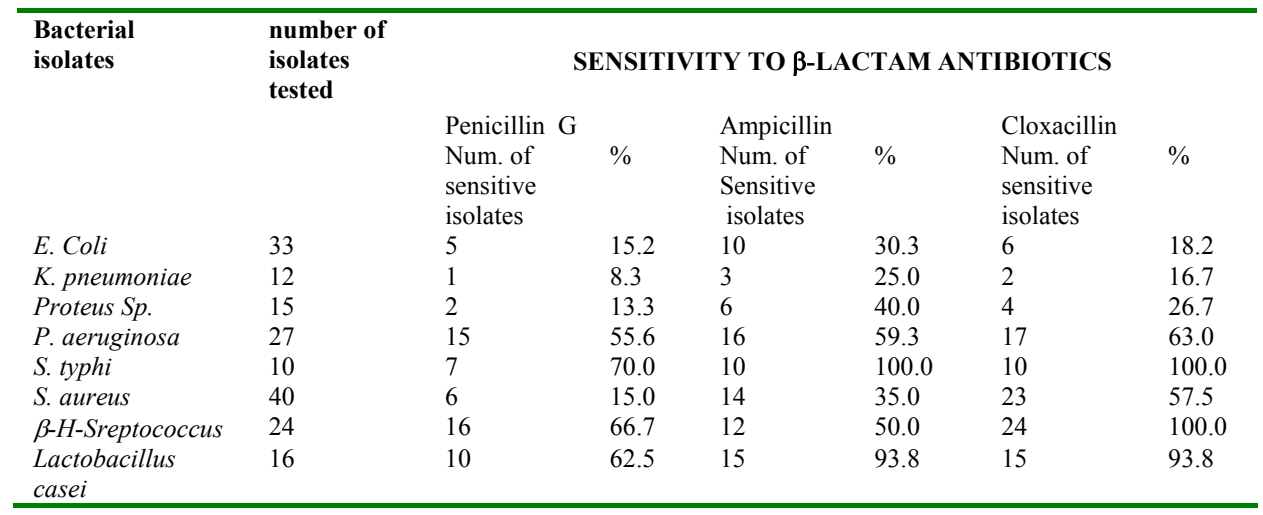

The results are in general agreement with the literature which has shown $67.0-90.0 \%$ for ampicillin and $85.0-98.0 \%$ for penicillin in some African countries including Nigeria (Lynne and Bernard, 1991; Rotimi et al., 1987). Ogarawa et al., (1978) suggested that the proportion of the producing Streptomyces strains isolated from the soil and the properties of the $\beta$-lactamase have not been affected significantly by the introduction of penicillin into the natural environment, in contrast to the cases of other organisms. $\beta$-lactamase production by the bacteria screened was positive in $44.6 \%$ of strains tested, when compared with the total bacterial isolates used in this work (table 3), this is lower than values reported, in a previous study on bacteria isolates obtained in hospital environment (Rotimi et al., 1987). The source of isolation of the organisms may be responsible for the lower values obtained.

\section{REFERENCES}

Appelbaum, P. C; Spangler, S. K; Pankuch, A; Philippon, A; Jacob, M. R; Shiman, R; Goldstein, E. J. C. and Citron, D. M. (1994). Characterization of a $\beta$-lactamase from Clostridium clostridioforme. J. Antimimicrob. Chemotherapy 33:33-40.

Barrow, G. I. and Feltham, R. K. A. (1995). Cowan and Steel's Manual for the identification of medical bacteria. $3^{\text {rd }}$ ed., Cambridge University Press London. 237pp.

Galan, J. C; Reig, M; Navas, A; Baquero, F. and Blazquez, J.(2000). AC I-I from Acidaminococus fermentans: Characterization of the first $\beta$-lactamase in anaerobic cocci. Servicio de microbiologia, Hospital Ramony Cajal Instituto Nacional de Salud (INSALUD), 28034 Madrid and Muceo Nacional de Ciencias Naturales, SCIC, 28006 Madrid Spain.

Lynne, J. D and Bernard, M. P. (1991). Epidemiology of $\beta$-lactamases in Africa, correlation with resistance to $\beta$-lactam Antibiotics 13(2). 243-251.

Obi, I. U. (2003). Statistical methods of detecting differences between treatment means and research methodology issues in laboratory and field experiments. ( $2^{\text {nd }}$ ed.,) Ap express publication Ltd. Nsukka, Nigeria.

Odungbemi, T. and Onile, B. A. (1988). Peadiatric gonorrhoeae: is it receiving adequate attention? Am. J. Reprod. Immunol. Microbiology 18: 32.

Ogarawa, H; Horikawa, S; Shamada-Miyoshi, S. and Yasuzawa, K. (1978). Production and property of $\beta$-lactamases in Steptomyces: Comparison of the strain isolated newly and thirty years ago: Journal Anticrobial Agents and Chemotheraphy 13 (5): 865-870.

Ogarawa, H; Kawamura, N; Kudo, T; Suzuki, K. I. and Nakase, T. (1999). Distribution of $\beta$ lactamase in Actinomycetes, Journal Antimicrobial Agents and chemotheraphy 43 (1): $3014-3017$.

Rotimi, V. O. (1989). Bacterial resistance to $\beta$ lactam antibiotics. Nigerian medical practitioner, 17(3): 39-44.

Rotimi, V. O; Orebanjo, O. A. and Banjo, T. O. (1987). Occurrence and antibiotic of methicillin - resistant Staphylococcus aureus in Lagos University Teaching Hospital. Cert. Africa Journal Med. 33:95.

Steel, R. G. O. and Torrie, J. H. (1980). Principles and procedures of statistics, Biometrical Approach, $\quad 2^{\text {nd }}$ edition, McGraw-Hill publishers. 